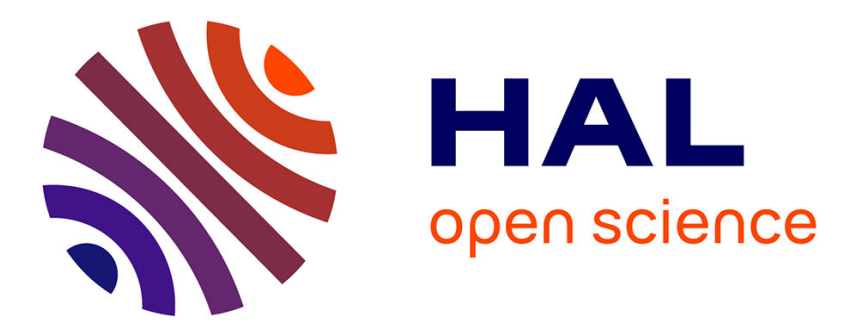

\title{
Co-pyrolysis of wood and plastics
}

Augustina Ephraim, Doan Pham Minh, Damien Lebonnois, Carlos Peregrina, Patrick Sharrock, Ange Nzihou

\section{To cite this version:}

Augustina Ephraim, Doan Pham Minh, Damien Lebonnois, Carlos Peregrina, Patrick Sharrock, et al.. Co-pyrolysis of wood and plastics: Influence of plastic type and content on product yield, gas composition and quality. Fuel, 2018, 231, p.110 - 117. 10.1016/j.fuel.2018.04.140 . hal-01802140

\section{HAL Id: hal-01802140 https://imt-mines-albi.hal.science/hal-01802140}

Submitted on 20 Oct 2018

HAL is a multi-disciplinary open access archive for the deposit and dissemination of scientific research documents, whether they are published or not. The documents may come from teaching and research institutions in France or abroad, or from public or private research centers.
L'archive ouverte pluridisciplinaire HAL, est destinée au dépôt et à la diffusion de documents scientifiques de niveau recherche, publiés ou non, émanant des établissements d'enseignement et de recherche français ou étrangers, des laboratoires publics ou privés. 


\title{
Co-pyrolysis of wood and plastics: Influence of plastic type and content on product yield, gas composition and quality
}

\author{
Augustina Ephraim ${ }^{\mathrm{a}, *}$, Doan Pham Minh ${ }^{\mathrm{a}}$, Damien Lebonnois ${ }^{\mathrm{b}}$, Carlos Peregrina ${ }^{\mathrm{b}}$, \\ Patrick Sharrock ${ }^{\mathrm{a}}$, Ange Nzihou ${ }^{\mathrm{a}}$ \\ ${ }^{\text {a } U n i v e r s i t e ́ ~ d e ~ T o u l o u s e, ~ M i n e s ~ A l b i, ~ R A P S O D E E ~ C N R S ~ U M R-5302, ~ C a m p u s ~ J a r l a r d, ~ F-81013 ~ A l b i ~ C e d e x ~ 09, ~ F r a n c e ~}$ \\ b SUEZ, 38, rue du Président Wilson, 78230 Le Pecq, France
}

\begin{abstract}
A B S T R A C T
In recent years, the world has witnessed a rapid rise in waste production and energy demand, which has increased interests in waste to energy processes, particularly the co-pyrolysis of wood and plastic waste. Nonetheless, for plastic waste, most research studies narrowly focus on polyolefins because of their abundance in waste streams and their high oil yields from pyrolysis. In this paper, we study the co-pyrolysis of non-polyolefins - polystyrene (PS) and polyvinyl chloride (PVC) - and poplar wood (PW), in order to investigate the synergistic effect of PS and PVC content on product yield, gas specie yield and heating value. The experiments were performed using a fixed-bed reactor, heated to $750{ }^{\circ} \mathrm{C}$ at a rate of $20^{\circ} \mathrm{C} / \mathrm{min}$ under nitrogen atmosphere. Our results show that PVC has a large positive synergy on char yield with a maximum value of $8 \mathrm{wt} \%$ at $30 \mathrm{wt} \% \mathrm{PVC}$ content, whereas PS only showed a slightly positive synergy (2.5 wt $\%$ maximum). Concerning oil and gas production, PS provides a small synergy. However, PVC showed a significant positive synergy on oil yield with a maximum value of $11 \mathrm{wt} \%$ at $50 \mathrm{wt} \%$ PVC content, which was linked to a strong negative synergy in gas production. Regarding gas specie yields, the addition of PS led to positive synergies in the formation of $\mathrm{H}_{2}, \mathrm{CH}_{4}, \mathrm{CO}$ and $\mathrm{CO}_{2}$, although insignificant interactions were observed for $\mathrm{C}_{x} \mathrm{H}_{y}$ compounds. Furthermore, by comparing the distribution of chloride species in the products of co-pyrolysis with PVC, using experimental and theoretical methods, we discovered that the negative synergy in $\mathrm{HCl}$ yield observed was mainly due to the dissolution of $\mathrm{HCl}$ in the water fraction of the condensed oil phase, rather than the formation of chlorinated organic compounds, as suggested in previous literature works. Our study therefore consolidates the understanding of the synergistic interactions between wood, PS and PVC co-pyrolysis, under conditions that favour gas production.
\end{abstract}

\author{
Keywords: \\ Waste \\ Co-pyrolysis \\ Wood \\ Polystyrene \\ Polyvinyl chloride \\ Thermodynamic equilibrium
}

\section{Introduction}

The rapid growth in world population over the last century combined with industrial development and urbanization has resulted in two major issues: the sharp increase in waste production and demand for energy. In Europe, the current generation rates of wood and plastic waste are 70.5 and $26.2 \mathrm{Mt} / \mathrm{yr}$ which are accompanied by low recycling rates of $31 \%$ and $17 \%$ respectively [1]. Hence, research into opportunities for converting wood and plastic waste to energy is strongly needed. Pyrolysis is a promising technique for recovering energy inherent in combustible solid waste which involves the thermal decomposition of the waste in an inert atmosphere to yield three primary products: gas $\left(\mathrm{H}_{2}, \mathrm{CO}, \mathrm{CO}_{2}, \mathrm{CH}_{4}\right.$ and light hydrocarbons), liquid hydrocarbons (tars and oils) and char (carbon material).

In recent years, co-pyrolysis of woody biomass and plastic waste has gained considerable research interest mainly due to the positive contribution of plastics to the product yield and the calorific value of the oil produced [2-6]. According to Johannes et al. [7], the interactions or synergy between biomass and plastics depends on various factors including the type and contact of the fuel components, pyrolysis duration, temperature and heating rate, and catalysts. Hence, it is not surprising that conflicting reports sometimes arise in literature concerning the differences between the actual and predicted yields of the pyrolysis products, where the predicted yields are calculated as linearly proportional to the contributions of the pure components. For example, Grieco and Baldi [8] observed insignificant interactions between low density polyethylene (LDPE) and beech wood during co-pyrolysis in a capsule at heating rates of 0.1 and $1{ }^{\circ} \mathrm{C} / \mathrm{s}$. However, Yang et al. [9] observed a significant synegistic effect on oil yield when LDPE and cedar wood were co-pyrolyzed at $600{ }^{\circ} \mathrm{C}$ in a dropdown tube reactor at rapid heating rates.

Research works on the co-pyrolysis of biomass and plastic waste

* Corresponding author

E-mail addresses: aug.ephraim@gmail.com, aephraim@mines-albi.fr (A. Ephraim). 
Table 1

Proximate analysis (as-received basis) of wood and plastic samples.

\begin{tabular}{llllll}
\hline \multicolumn{1}{l}{ Moisture (\%) } & Ash (\%) & $\begin{array}{l}\text { Volatile matter } \\
(\%)\end{array}$ & $\begin{array}{l}\text { Fixed carbon } \\
(\%)\end{array}$ & $\begin{array}{l}\text { LHV (MJ/ } \\
\mathrm{kg})\end{array}$ \\
\hline PW & 8.0 & 2.0 & 85.1 & 4.0 & 17.1 \\
PS & 0.0 & 0.0 & 99.6 & 0.4 & 39.8 \\
PVC & 0.0 & 0.0 & 95.8 & 4.2 & 19.3 \\
\hline
\end{tabular}

Table 2

Ultimate analysis (dry ash-free basis) of wood and plastic samples.

\begin{tabular}{lllllll}
\hline & $\mathrm{C} \mathrm{( \% )}$ & $\mathrm{H}(\%)$ & $\mathrm{O}(\%)$ & $\mathrm{N}(\%)$ & $\mathrm{S} \mathrm{( \% )}$ & $\mathrm{Cl}(\%)$ \\
\hline PW & 49.9 & 6.4 & 42.7 & 1.0 & 0.0 & 0.01 \\
PS & 92.4 & 7.8 & 0.0 & 0.0 & 0.0 & 0.0 \\
PVC & 38.7 & 4.8 & 0.0 & 0.0 & 0.0 & 56.5 \\
\hline
\end{tabular}

have principally focused on the influence of temperature, heating rate and reaction time on product yield and quality [10-13]. Nonetheless, some authors, such as Oyedun et al. [14] have shown that the type and plastic content in the sample also play an important role. Unfortunately, the few studies on the influence of plastic content on product yield are narrowly-focused on polyolefins (polyethylene (PE) or polypropylene (PP)) because this plastic type generates high oil yields and is the most abundant in waste streams $[15,8,16]$. Consequently, the operating conditions chosen for these studies aim at maximising oil yields for liquid fuel production and involve low temperatures $\left(400-500{ }^{\circ} \mathrm{C}\right)$, and short gas residence times $(<15 \mathrm{~min})$. Furthermore, with respect to research works on the influence of plastic content in biomass on gas composition and heating value, Grieco et al. [8] and Paradela et al.[12] have observed significant interactions. However, Paradela et al. [12] conducted their experiments with a fixed plastic waste mixture of $56 \mathrm{wt}$ $\%$ PE, $17 \mathrm{wt} \%$ PS and $27 \mathrm{wt} \% \mathrm{PP}$ and Grieco et al. [8] performed theirs using only PE as the plastic type. Hence, there remains a knowledge gap in literature about the contribution of non-polyolefins such as PS and PVC on the gas composition and heating value derived from co-pyrolysis with biomass.

Thus, in this work, we will investigate the influence of PS and PVC content in wood on the co-pyrolysis product yields, gas specie yields and heating value, under conditions that favour gas production: high temperature, low heating rate and long gas residence time.

\section{Experimental methods}

\subsection{Wood and plastic samples}

The materials used for the tests were poplar wood (PW), PVC and PS, whose characterstics are displayed in Tables 1 and 2. The particle size of each pure material was less than $1 \mathrm{~mm}$. Several wood/plastic mixtures for each plastic type were prepared having different plastic contents: $0-5-10-30-50-100 \mathrm{wt} \%$ plastic.

\subsection{Pyrolysis reactor and procedure}

Fig. 1 gives a schematic representation of the experimental setup. For each test, $10 \mathrm{~g}$ of sample was placed in a quartz crucible. The sample was heated in a furnace to $750^{\circ} \mathrm{C}$ at a heating rate of $20^{\circ} \mathrm{C} / \mathrm{min}$ under nitrogen atmosphere $(33 \mathrm{~mL} / \mathrm{min})$ and was maintained at this temperature for $30 \mathrm{~min}$ before being cooled to room temperature. These operating conditions allowed a reaction time of $66 \mathrm{~min}$ which is sufficient for secondary cracking of volatiles to occur in order to form more gas and secondary char. At the reactor outlet, the volatile oil was condensed in an impinger bottle filled with cotton wool and cooled to $0^{\circ} \mathrm{C}$. Thus, in this case, the term 'oil' represents a mixture of bio-tar, oil, wax and small amounts of water produced from the pyrolysis process. For experiments with PVC, the oil condenser was replaced with two impinger bottles containing aqueous solutions of $\mathrm{KOH}$ to trap $\mathrm{HCl}$ gas. Next, the total amount of the non-condensable gas produced from pyrolysis was collected in a Tedlar bag. Its composition was analyzed by a micro-gas chromatograph (Micro-GC, A3000 Agilent). The quantification of $\mathrm{HCl}$ concentration in the aqueous phase was conducted using $\mathrm{X}$-ray fluorescence (XRF, PANanalytical).

The char yield was calculated by dividing the weight loss of the sample and crucible before and after pyrolysis by the total initial sample mass. The gas yield $y_{g a s}$, was calculated based on the following equations:

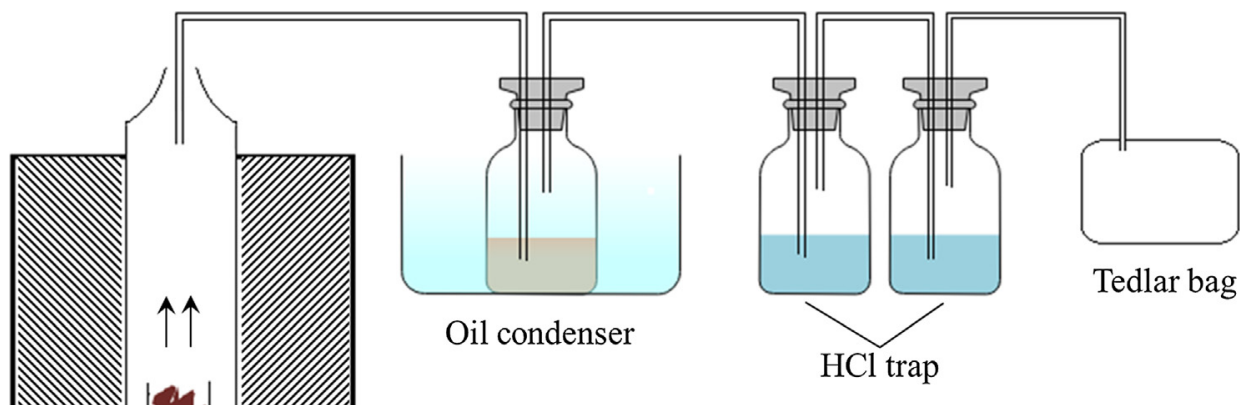

Fig. 1. Experimental setup of pyrolysis equipments. 


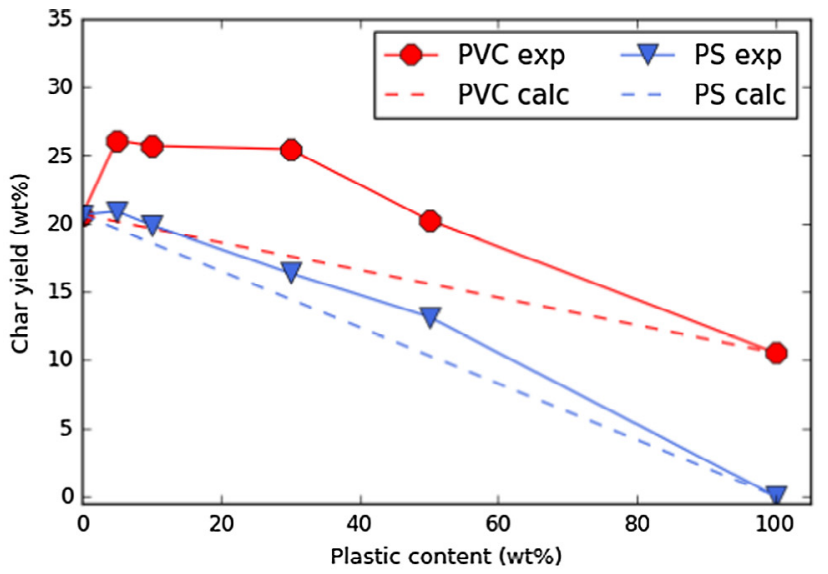

(a) Char yield

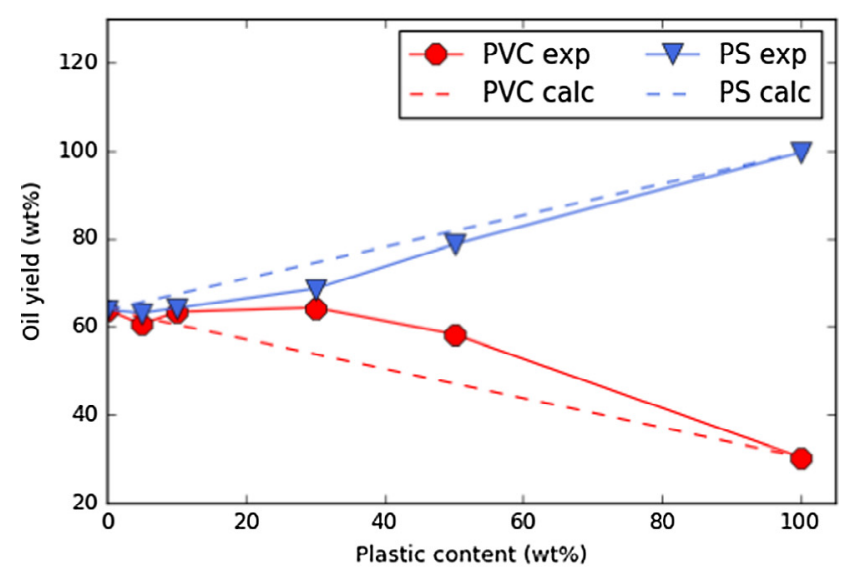

(b) Oil yield

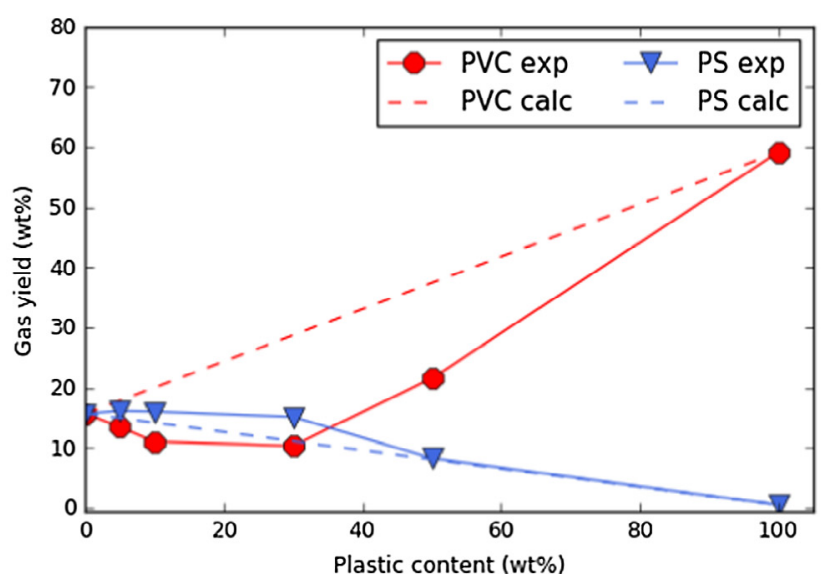

(c) Gas yield

Fig. 2. Influence of plastic type and content on product yield.

$V_{g a s}=\frac{Q_{N_{2}} t}{x_{N_{2}}}$

$y_{\text {gas }}=\frac{\sum_{i}^{n}\left(\rho_{i} x_{i}\right) V_{\text {gas }}}{m_{s}}$

where $V_{\text {gas }}$ is the total gas volume, $Q_{N_{2}}$ and $x_{N_{2}}$ are the volumetric flowrate and volume fraction of the nitrogen carrier gas respectively, $t$ is the reaction time, $\rho_{i}$ and $x_{i}$ are the density and volume fraction of each gas specie $i$, measured at normal temperature and pressure, and $m_{s}$ is the initial sample mass. To estimate the oil yield, the difference between the yields of char and gas was calculated.

The gas lower heating value $L H V_{\text {gas }}$ in units of $\mathrm{MJ} / \mathrm{Nm}^{3}$ was estimated based on the lower heating values of each gas specie $i(\mathrm{MJ} / \mathrm{kg})$, using the following equation:

$L H V_{\text {gas }}=\sum_{i}^{n} L H V_{i} \rho_{i} x_{i}$

To evaluate the synergy between poplar wood and the plastic samples, the theoretical product yields were calculated according to the following formula:

$y_{\text {calc }}=w_{1} y_{1}+w_{2} y_{2}$

where $y_{1}$ and $y_{2}$ are the pyrolysis yields of pure wood and plastic; $w_{1}$ and $w_{2}$ are the mass proportions of wood and plastic in the sample respectively. Therefore, the interaction or synergy parameter $\Delta y$, is the difference between the experimental and calculated product yields from co-pyrolysis.

$\Delta y=y_{\text {exp }}-y_{\text {calc }}$

\section{Results}

\subsection{Effect on char yield}

Fig. 2 and Table 3 present the yields of char, oil and gas with respect to the different plastic contents in the samples. It can be seen in Table 3 that the char yield from pure PW pyrolysis is $20.6 \mathrm{wt} \%$ whereas half as much char is produced from pure PVC (10.5 wt\%) and virtually no char is produced from pure PS. Williams et al. [17] have obtained similar values for char yield from the pyrolysis of these pure plastics.

Regarding the co-pyrolysis of PW and PS, a small positive synergy can be observed in Fig. 2a with a maximum difference of approximately $2.5 \mathrm{wt} \%$ between the experimental and theoretical char yield. This indicates that the presence of PS promotes secondary reactions of volatiles, such as condensation and repolymerisation, to form secondary char.

For co-pyrolysis with PVC, a strong positive synergy can be seen in Fig. 2a, where the maximum synergy of $8 \mathrm{wt} \%$ occurs at a PVC content of $30 \mathrm{wt} \%$. Cepeliogullar and Putun [18] have also obtained significantly higher char yields compared with the theoretical yield for a mixture of 1:1 weight ratio of PVC and biomass (hazelnut shell, sunflower residues and E. rigida). An explanation for this phenomenon could be drawn from the work of Matsuzawa et al. $[19,20]$ who suggest that $\mathrm{HCl}$ produced from PVC pyrolysis promotes the dehydration and cross-linking of cellulose in biomass, which in turn promotes the charring of cellulose.

\subsection{Effect on oil and gas yields}

As shown in Table 3, the oil and gas yield of pure PW is $63.7 \mathrm{wt} \%$ and $15.7 \mathrm{wt} \%$. Pure PS generates a high oil yield of $99.5 \mathrm{wt} \%$, due to its relatively high volatile and low ash content (Table 1). Thus, the oil yield from PS/PW co-pyrolysis increases with PS content, which follows a similar trend reported in literature for co-pyrolysis with other biomass types at temperatures of roughly $400{ }^{\circ} \mathrm{C}[3,21-23]$. However, in Fig. $2 \mathrm{~b}$, a negative synergy can be observed for PS/PW co-pyrolysis, which has not yet been demonstrated in literature. Oyedun et al. [14] have found from thermogravimetric analysis, that lower temperature and energy are required to pyrolyze PS/biomass blends than are required for the pyrolysis of other mixtures such as HDPE/biomass. It is therefore possible, in our opinion, that the oil formed at lower temperatures in the presence of PS has more time to undergo secondary cracking reactions to produce more gaseous products, and thereby decrease the overall oil 
Table 3

Product yield from the pyrolysis of PW, PVC, PS and their mixtures

\begin{tabular}{|c|c|c|c|c|c|c|}
\hline \multirow[b]{2}{*}{$\begin{array}{l}\text { Plastic } \\
\text { Content (wt\%) }\end{array}$} & \multicolumn{3}{|c|}{ PVC } & \multicolumn{3}{|c|}{ PS } \\
\hline & $\begin{array}{l}\text { Char } \\
\text { (wt\%) }\end{array}$ & $\begin{array}{l}\text { Gas } \\
\text { (wt } \%)\end{array}$ & $\begin{array}{l}\text { Oil }^{*} \\
(w t \%)\end{array}$ & $\begin{array}{l}\text { Char } \\
\text { (wt } \%)\end{array}$ & $\begin{array}{l}\text { Gas } \\
\text { (wt } \%)\end{array}$ & $\begin{array}{l}\text { Oil* } \\
\text { (wt } \%)\end{array}$ \\
\hline 0 (100 wt $\%$ PW) & 20.6 & 15.7 & 63.7 & 20.6 & 15.7 & 63.7 \\
\hline 5 & 26.1 & 13.5 & 60.5 & 20.9 & 16.1 & 63.0 \\
\hline 10 & 25.7 & 11.0 & 63.3 & 19.9 & 16.0 & 64.2 \\
\hline 30 & 25.4 & 10.3 & 64.2 & 16.3 & 15.1 & 68.6 \\
\hline 50 & 20.2 & 21.5 & 58.2 & 13.1 & 8.30 & 78.6 \\
\hline 100 & 10.5 & 59.2 & 30.3 & 0.00 & 0.50 & 99.5 \\
\hline
\end{tabular}

* Calculated by difference and represents a mixture of bio-tar, oil, wax and water.

yield. This suggestion is supported by the observation, in Fig. 2c, that the gas yield increases relative to the predicted yield for PS contents below $50 \mathrm{wt} \%$.

Pure PVC has a relatively low oil yield (30.3 wt\%) and high gas yield (59.2 wt\%) compared to PW and PS. By observing Fig. 2b, the copyrolysis of PVC and PW has a positive synergistic effect on oil yield, with a maximum synergy of $11 \mathrm{wt} \%$ at $50 \mathrm{wt} \%$ PVC content. A corresponding strongly negative synergy in gas yield can be seen in Fig. 2c, where the maximum synergy of $18 \mathrm{wt} \%$ occurs at $30 \mathrm{wt} \%$ PVC content. Zhou et al. [24] have recently observed a significant increase in oil yield for mixtures of PVC with three biomass components - hemicellulose, cellulose and lignin - during fast co-pyrolysis at $800{ }^{\circ} \mathrm{C}$ in a fixed bed reactor. They propose that the biomass and/or bio-char can act as a catalyst to promote chain scission of PVC, resulting in the increased production of chlorinated oil compounds. This theory will be examined in Section 3.5.

\subsection{Effect on gas specie yields}

Table 4 displays the yield of light gases derived from the co-pyrolysis of the different plastic and wood samples, and Table 5 shows the yield of the heavier hydrocarbon gases produced, which we will conveniently refer to as $\mathrm{C}_{x} \mathrm{H}_{y}$. In Fig. 3 , the variation of the various gas specie yields as a function of plastic content is presented, which reveals non-linear trends and therefore, the existence of interactions between PW and plastics.

Concerning PS, the yields of the gas species generally decrease as PS content in PW increases because oil production is favoured by this plastic (Fig. 2b). However, significant positive synergies can be observed for $\mathrm{H}_{2}, \mathrm{CH}_{4}, \mathrm{CO}$ and $\mathrm{CO}_{2}$, and to a lesser degree for $\mathrm{C}_{x} \mathrm{H}_{y}$ compounds. This implies, that secondary reactions occur between PS and the wood volatile products to promote the formation of lighter gases.

In Fig. 3, we can observe that PVC contents below $50 \mathrm{wt} \%$ in $\mathrm{PW}$ results in negative synergies for $\mathrm{CH}_{4}, \mathrm{C}_{x} \mathrm{H}_{y}, \mathrm{CO}$ and $\mathrm{CO}_{2}$ yields. This indicates that interactions between PVC and PW favours the production of oxygenated hydrocarbons in the oil and char products. Nonetheless, a positive synergy for $\mathrm{H}_{2}$ yield can be seen, which in our opinion, may be due to enhanced condensation and cyclization reactions of polyene species produced from the dechlorination of PVC. These cyclization reactions of polyene take place via both radical and molecular mechanisms to form $\mathrm{H}_{2}$, polycyclic aromatic hydrocarbons (PAH) and char [25]. Our proposed mechanism for enhanced $\mathrm{H}_{2}$ production is supported by the recent works of Çepelioullar et al. [18,26] who obtained an increased amount of PAH from the co-pyrolysis of PVC and biomass mixtures.

It is interesting to observe in Fig. $3 \mathrm{~b}$ that although $\mathrm{HCl}$ yield increases as a function of PVC content, a strong negative synergy can be observed, whereby $\mathrm{HCl}$ gas yield was found to decrease by $53.6 \mathrm{wt} \%$ when PVC content was decreased from 100 to $30 \mathrm{wt} \%$. This result is consistent with a recent TG-FTIR analysis by Zhou et al. [27] who report that, compared to pure PVC pyrolysis, the maximum $\mathrm{HCl}$ peak strongly weakens when PVC is co-pyrolysed with orange peel and tissue paper in a 1:1 weight ratio mixture. Furthermore, Kuramochi et al. [28] have reported a significant reduction in $\mathrm{HCl}$ emission when demolition wood is co-pyrolyzed with $1 \mathrm{wt} \%$ PVC film. However, the mechanism for HCl-biomass interaction is not well-defined in literature [29]. Kuramochi et al. [28] have pyrolyzed mixtures of PVC with three constituents of biomass (cellulose, hemicellulose and lignin) separately. Their results show that cellulose has an insignificant effect on $\mathrm{HCl}$ emission, whereas hemicellulose, and lignin to a lesser extent, reduce $\mathrm{HCl}$ emissions by fixing most of the $\mathrm{Cl}$ molecules in the char product. A contradictory result has been presented by Zhou et al. [30] who have found that cellulose can also decrease $\mathrm{HCl}$ emission to a similar degree as hemicellulose and lignin. To further add to the confusion, another recent work by the same author suggests that the $\mathrm{Cl}$ molecules are fixed in the liquid product to form chlorinated oil compounds [24]. It is therefore evident that more investigations are needed to better understand the mechanisms that govern the interactions between $\mathrm{HCl}$ and biomass during co-pyrolysis with PVC. This point will be further addressed in Section 3.5.

\subsection{Effect on gas heating value}

Table 6 and Fig. 4 present the evolution of the gas lower heating value (LHV) with plastic content. Factors that can increase the LHV of a gas include high concentrations of hydrogen and hydrocarbons. Fig. 4 shows that at conditions of normal temperature $\left(20^{\circ} \mathrm{C}\right)$ and atmospheric pressure, the LHV of gas derived from pure PW pyrolysis is about $19 \mathrm{MJ} / \mathrm{Nm}^{3}$, while higher LHV values are observed for pure PS and PVC in the order of 23 and $26 \mathrm{MJ} / \mathrm{Nm}^{3}$ respectively. However, the gas LHV is observed to not vary significantly with plastic content below $50 \mathrm{wt} \%$, because the hydrogen and carbon content of these plastics preferentially distribute to the oil product of PS, and the char and $\mathrm{HCl}$ gas products of PVC.

\subsection{Effect of PVC content on chlorine distribution}

Fig. 5 presents the distribution of $\mathrm{Cl}$ molecules in the char, gas and condensed oil (bio-tar, oil, wax and water) products as a function of the

Table 4

Light gas yields from the pyrolysis of PW, PVC, PS and their mixtures.

\begin{tabular}{|c|c|c|c|c|c|c|c|c|c|}
\hline \multirow[b]{2}{*}{$\begin{array}{l}\text { Plastic } \\
\text { Content (wt \%) }\end{array}$} & \multicolumn{5}{|c|}{ PVC } & \multicolumn{4}{|c|}{ PS } \\
\hline & $\begin{array}{l}\mathrm{H}_{2} \\
(\mathrm{wt} \%)\end{array}$ & $\begin{array}{l}\mathrm{CH}_{4} \\
(\mathrm{wt} \%)\end{array}$ & $\begin{array}{l}\mathrm{CO} \\
(\mathrm{wt} \%)\end{array}$ & $\begin{array}{l}\mathrm{CO}_{2} \\
(\mathrm{wt} \%)\end{array}$ & $\begin{array}{l}\mathrm{HCl} \\
(\mathrm{wt} \%)\end{array}$ & $\begin{array}{l}\mathrm{H}_{2} \\
(\mathrm{wt} \%)\end{array}$ & $\begin{array}{l}\mathrm{CH}_{4} \\
\text { (wt\%) }\end{array}$ & $\begin{array}{l}\mathrm{CO} \\
\text { (wt } \%)\end{array}$ & $\begin{array}{l}\mathrm{CO}_{2} \\
(\mathrm{wt} \%)\end{array}$ \\
\hline 0 (100 wt $\%$ PW) & 0.16 & 1.54 & 6.10 & 7.17 & 0.10 & 0.16 & 1.54 & 6.10 & 7.17 \\
\hline 5 & 0.20 & 1.36 & 4.80 & 6.15 & 0.48 & 0.18 & 1.59 & 6.66 & 6.89 \\
\hline 10 & 0.19 & 1.12 & 3.85 & 4.97 & 0.56 & 0.18 & 1.59 & 6.52 & 6.95 \\
\hline 30 & 0.25 & 1.24 & 3.57 & 3.62 & 1.19 & 0.21 & 1.52 & 6.20 & 6.53 \\
\hline 50 & 0.26 & 1.31 & 3.73 & 3.66 & 11.90 & 0.15 & 0.87 & 3.46 & 3.34 \\
\hline 100 & 0.36 & 2.50 & 0.07 & 0.05 & 54.79 & 0.03 & 0.18 & 0.15 & 0.03 \\
\hline
\end{tabular}


Table 5

Hydrocarbon gas $\left(\mathrm{C}_{x} \mathrm{H}_{y}\right)$ yields from the pyrolysis of PW, PVC, PS and their mixtures.

\begin{tabular}{|c|c|c|c|c|c|c|}
\hline \multirow[b]{2}{*}{$\begin{array}{l}\text { Plastic } \\
\text { Content (wt\%) }\end{array}$} & \multicolumn{3}{|c|}{ PVC } & \multicolumn{3}{|c|}{ PS } \\
\hline & $\begin{array}{l}\mathrm{C}_{2} \mathrm{H}_{4} \\
(\mathrm{wt} \%)\end{array}$ & $\begin{array}{l}\mathrm{C}_{2} \mathrm{H}_{6} \\
\text { (wt \%) }\end{array}$ & $\begin{array}{l}\mathrm{C}_{3} \mathrm{H}_{8} \\
(\mathrm{wt} \%)\end{array}$ & $\begin{array}{l}\mathrm{C}_{2} \mathrm{H}_{4} \\
\text { (wt \%) }\end{array}$ & $\begin{array}{l}\mathrm{C}_{2} \mathrm{H}_{6} \\
(\mathrm{wt} \%)\end{array}$ & $\begin{array}{l}\mathrm{C}_{3} \mathrm{H}_{8} \\
(\mathrm{wt} \%)\end{array}$ \\
\hline 0 (100 wt $\%$ PW) & 0.26 & 0.20 & 0.19 & 0.26 & 0.20 & 0.19 \\
\hline 5 & 0.19 & 0.12 & 0.13 & 0.38 & 0.18 & 0.22 \\
\hline 10 & 0.13 & 0.12 & 0.11 & 0.34 & 0.18 & 0.24 \\
\hline 30 & 0.18 & 0.17 & 0.13 & 0.34 & 0.15 & 0.15 \\
\hline 50 & 0.23 & 0.29 & 0.17 & 0.28 & 0.10 & 0.09 \\
\hline 100 & 0.69 & 0.45 & 0.24 & 0.09 & 0.01 & 0.00 \\
\hline
\end{tabular}

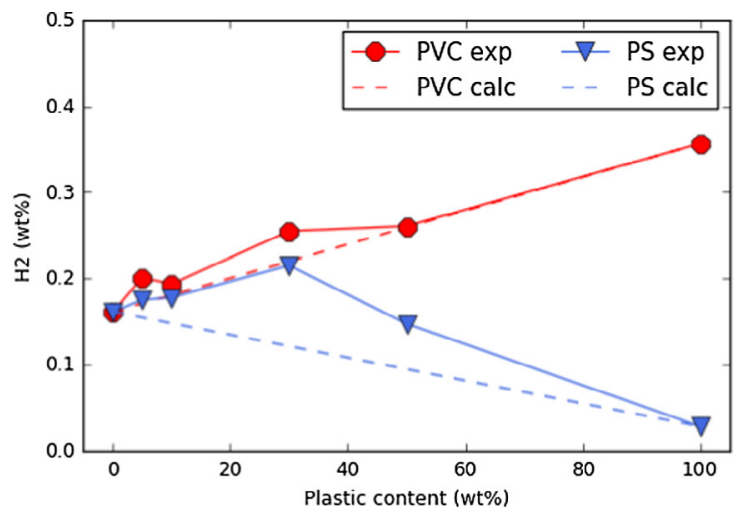

(a) $\mathrm{H} 2$

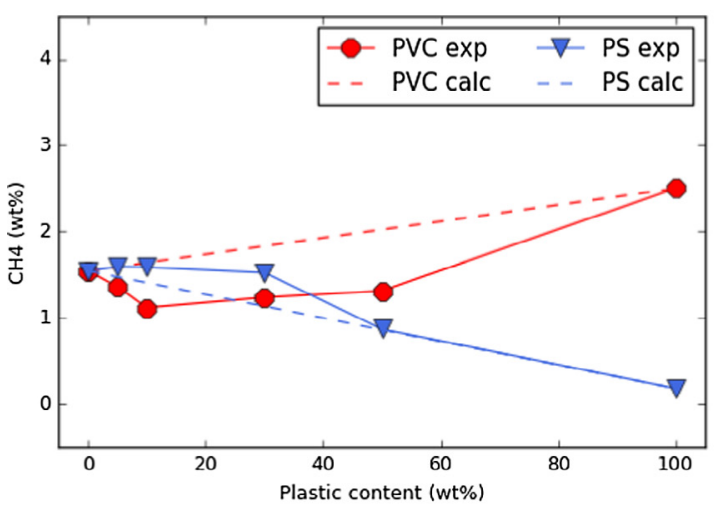

(c) $\mathrm{CH} 4$

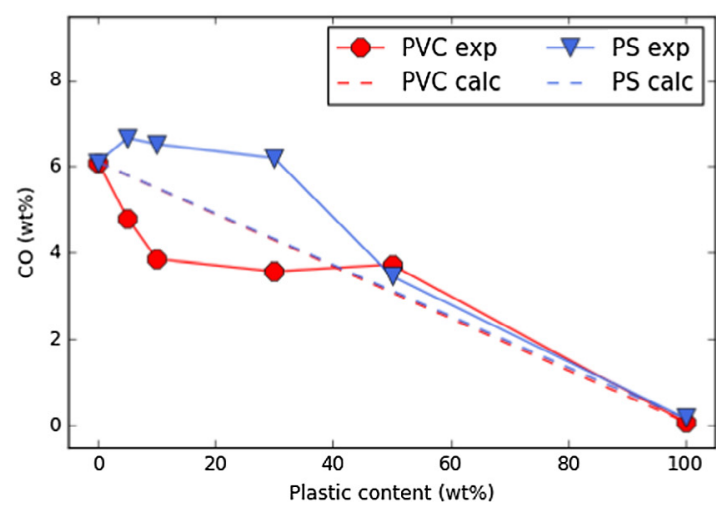

(e) $\mathrm{CO}$
PVC content in the sample mixture with PW. The $\mathrm{Cl}$ content in the char and condensed gas products were analysed using $\mathrm{X}$-ray fluorescence (XRF, PANanalytical) and the $\mathrm{Cl}$ content in oil was calculated by difference. The corresponding yields of $\mathrm{Cl}$ in the pyrolysis products were then determined on the basis of the initial mass of $\mathrm{Cl}$ in the PVC/PW samples. It can be observed in Fig. 5 that products from pure PW pyrolysis contain insignificant amounts of $\mathrm{Cl}$ whereas for pure PVC, $96.9 \mathrm{wt}$ $\%$ of $\mathrm{Cl}$ is released in the gas phase, thus leaving only 2.9 and $0.04 \mathrm{wt} \%$ $\mathrm{Cl}$ in the oil and char phase respectively. Compared to the products of pure PVC pyrolysis, the $\mathrm{Cl}$ yield decreases in the gas phase by $89.9 \mathrm{wt} \%$ when the PVC content is lowered from $100 \mathrm{wt} \%$ to $30 \mathrm{wt} \%$, and the corresponding $\mathrm{Cl}$ yields in the oil and char products increase by 76.2 and $13.8 \mathrm{wt} \%$ respectively. Furthermore, even at a low PVC content of $5 \mathrm{wt} \%$, the $\mathrm{Cl}$ distribution in oil is significantly higher than in the char and gas phases. Hence, it is clear that the $\mathrm{Cl}$ molecules from co-pyrolysis

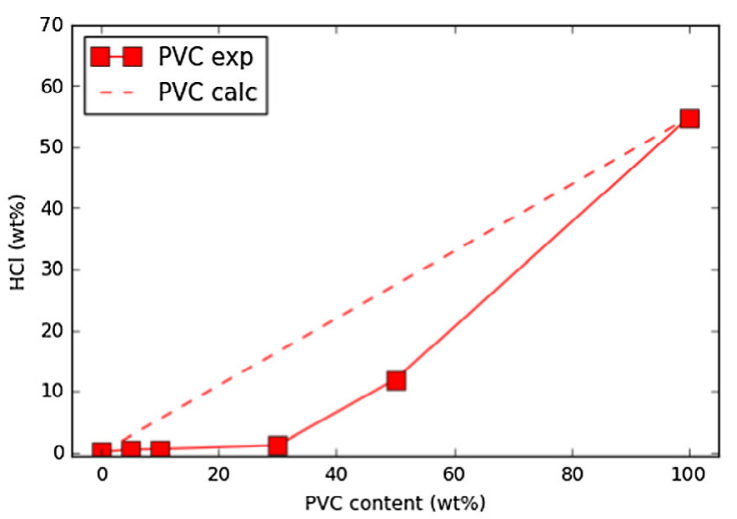

(b) $\mathrm{HCl}$

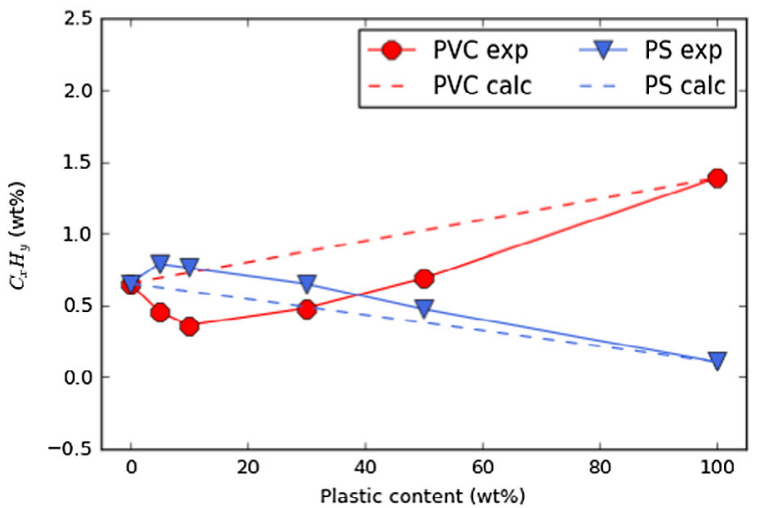

(d) $\mathrm{C} x \mathrm{H} y$

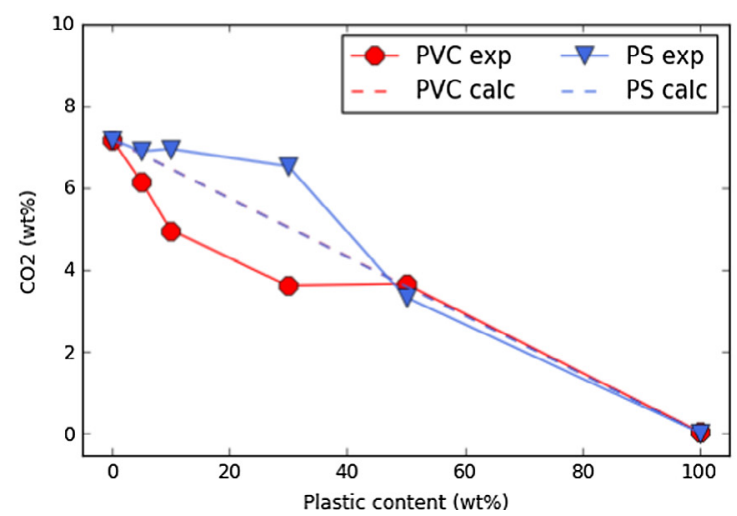

(f) $\mathrm{CO} 2$

Fig. 3. Influence of plastic type and content on gas composition. 
Table 6

Gas lower heating value (MJ/Nm3) from the pyrolysis of PW, PVC, PS and their mixtures.

\begin{tabular}{lcc}
\hline & PVC & PS \\
\hline $0(100 \mathrm{wt} \% \mathrm{PW})$ & 18.9 & 18.9 \\
5 & 18.2 & 19.0 \\
10 & 17.9 & 19.0 \\
30 & 18.2 & 18.3 \\
50 & 18.5 & 19.0 \\
100 & 25.6 & 22.8 \\
\hline
\end{tabular}

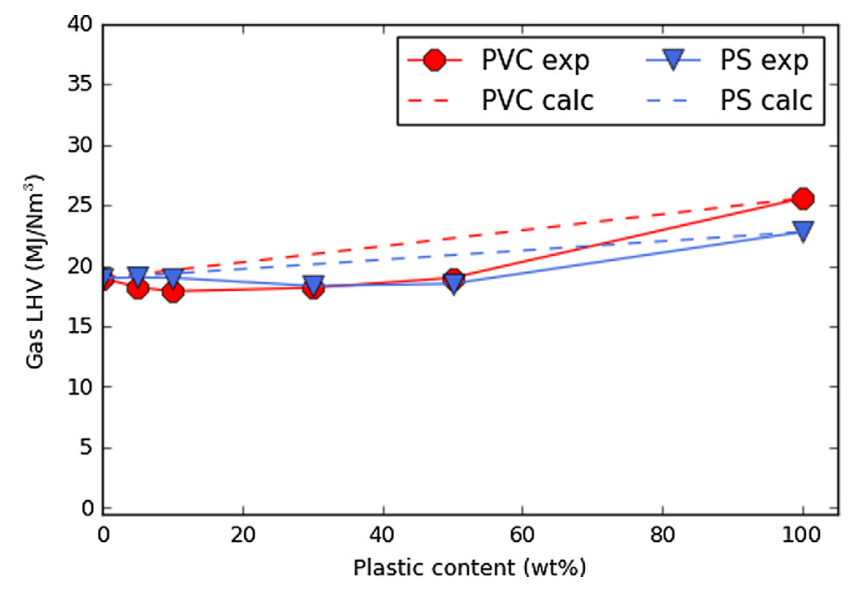

Fig. 4. Influence of plastic type and content on gas heating value.

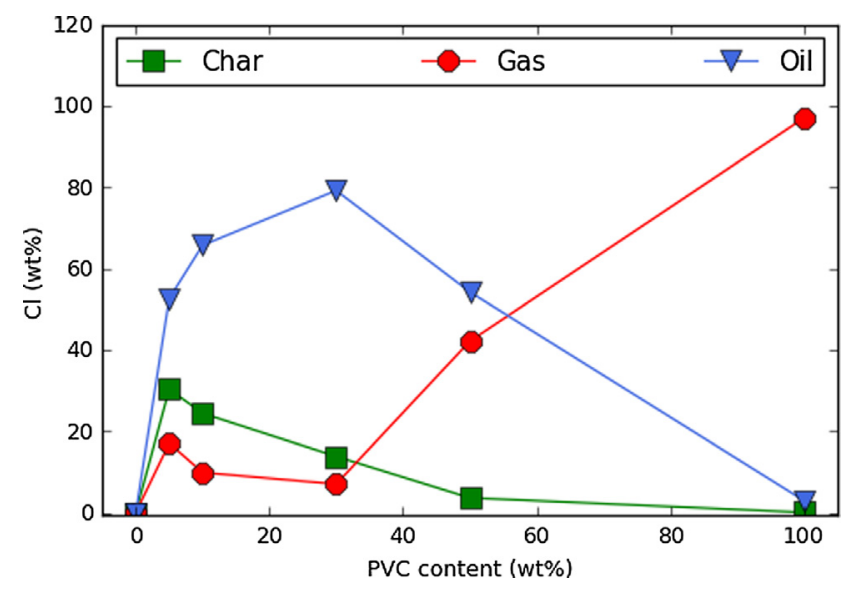

Fig. 5. Influence of PVC content on distribution of chlorine in char, gas and oil products.

of $\mathrm{PVC} / \mathrm{PW}$ are preferentially trapped in the oil product. Our result therefore supports the aforementioned hypothesis presented by Zhou et al. [24] that the $\mathrm{Cl}$ molecules are fixed in the oil product.

A further investigation was made to predict the distribution of chloride species in the char, gas and oil products, using thermodynamic equilibrium calculations based on the Gibbs free energy minimization approach. These calculations were performed using FactSage V.6.3. and a database developed by Said et al. [31]. The chosen input data for the calculations are:

- Feedstock: $10 \mathrm{~g}$ of $30 \mathrm{wt} \% \mathrm{PVC} / \mathrm{PW}$, with its composition of organic and inorganic elements displayed in Table 7.

- Reactor temperature range: $150-750^{\circ} \mathrm{C}$.

- Reactor pressure: $1 \mathrm{~atm}$

Figs. $6 \mathrm{a}$ and $\mathrm{b}$ display the equilibrium mass percentages of inorganic
Table 7

Elementary composition of $30 \mathrm{wt} \% \mathrm{PVC} / \mathrm{PW}$.

\begin{tabular}{|c|c|}
\hline & $30 \mathrm{wt} \% \mathrm{PVC} / \mathrm{PW}$ \\
\hline \multicolumn{2}{|c|}{ Organic elements (wt.\%) } \\
\hline $\mathrm{N}$ & 0.7 \\
\hline C & 46.6 \\
\hline $\mathrm{H}$ & 5.9 \\
\hline s & 0.0 \\
\hline $\mathrm{O}$ & 29.4 \\
\hline $\mathrm{Cl}$ & 16.9 \\
\hline \multicolumn{2}{|c|}{ Inorganic elements (ppm) } \\
\hline $\mathrm{Al}$ & 131 \\
\hline As & 52 \\
\hline B & 27 \\
\hline $\mathrm{Ba}$ & 20 \\
\hline $\mathrm{Ca}$ & 2787 \\
\hline $\mathrm{Cd}$ & 20 \\
\hline Co & 23 \\
\hline $\mathrm{Cr}$ & 24 \\
\hline $\mathrm{Cu}$ & 77 \\
\hline $\mathrm{Fe}$ & 56 \\
\hline $\mathrm{Hg}$ & 10 \\
\hline $\mathrm{K}$ & 459 \\
\hline $\mathrm{Mg}$ & 269 \\
\hline Mn & 32 \\
\hline Mo & 28 \\
\hline $\mathrm{Na}$ & 268 \\
\hline $\mathrm{Ni}$ & 26 \\
\hline $\mathrm{P}$ & 238 \\
\hline $\mathrm{Pb}$ & 69 \\
\hline $\mathrm{Sb}$ & 76 \\
\hline Se & 91 \\
\hline $\mathrm{Si}$ & 133 \\
\hline Sn & 190 \\
\hline $\mathrm{Sr}$ & 21 \\
\hline $\mathrm{Ti}$ & 26 \\
\hline V & 26 \\
\hline $\mathrm{Zn}$ & 32 \\
\hline $\mathrm{Zr}$ & 24 \\
\hline
\end{tabular}

and organic chloride species with respect to the total mass of chloride species and as a function of temperature, respectively. Fig. 6a shows that above $200^{\circ} \mathrm{C}, 95 \mathrm{wt} \%$ of chloride species is released into the gas phase as $\mathrm{HCl}$. In addition, $\mathrm{Cl}$ is mainly trapped in the inorganic solid phase as $\mathrm{CaCl}_{2}$ (4t\%). It is interesting to observe in Fig. $6 \mathrm{~b}$ that organic chloride species are formed in trace amounts, the most abundant of which is dimethyl phosphinic chloride $\left(\mathrm{C}_{2} \mathrm{H}_{6} \mathrm{ClOP}\right)$, which forms a pinkish-white crystal at room temperature.

By comparing the predicted yields of chloride species from the thermodynamic equilibrium calculations, with those obtained experimentally from the pyrolysis of $30 \mathrm{wt} \%$ PVC/PW (Fig. 5), we can first conclude that chlorinated hydrocarbons are only in trace amounts in the condensed oil phase (a mixture of bio-tar, oil, wax and water), which contradicts the proposal by Zhou et al. [24]. Secondly, we propose that the high chlorine content observed in the oil phase is mainly due to $\mathrm{HCl}$ gas dissolved in the water fraction of the oil upon condensation. This statement is supported by our observation in Fig. 5 that $\mathrm{HCl}$ yield in the gas phase has a similar but opposite trend to the chloride species yield in the oil phase with respect to the initial PVC content in the sample. Future work should be done on the analysis of organic chlorinated compounds in the oil phase, using for example GCMSMS technique.

\section{Conclusion}

Experimental work on the co-pyrolysis of poplar wood (PW) and the plastics, PS and PVC, has been presented in this paper in which different synergistic effects of plastic type and content on product yield, gas specie yield and gas heating value were studied. 


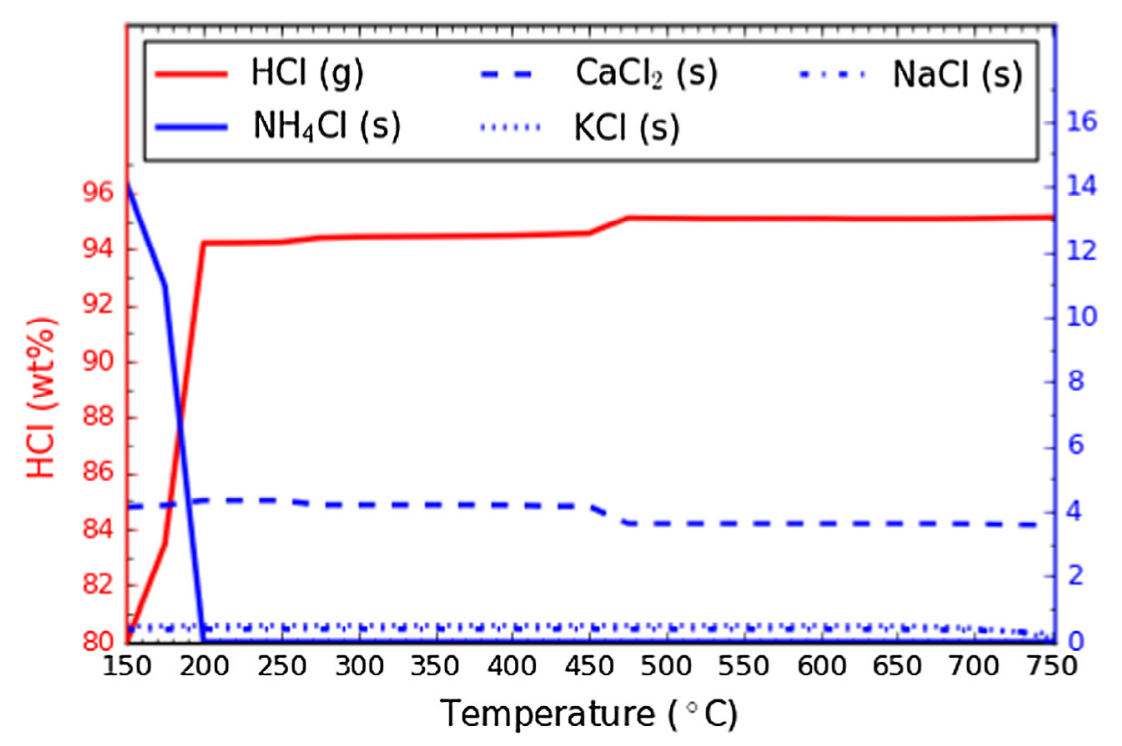

(a) Inorganic chloride species

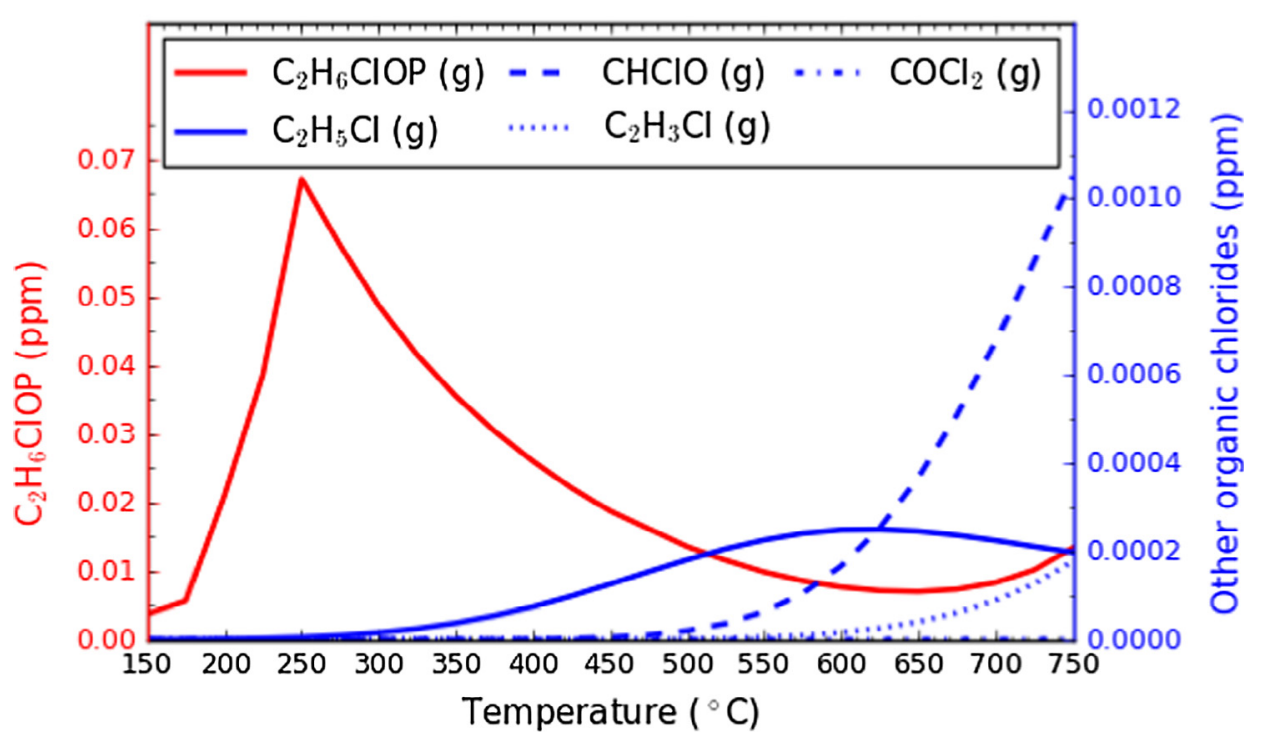

(b) Organic chloride species

Fig. 6. Theoretical chloride species yield from the pyrolysis of $30 \mathrm{wt} \% \mathrm{PVC} / \mathrm{PW}$ between $150{ }^{\circ} \mathrm{C}$ and $750{ }^{\circ} \mathrm{C}, 1 \mathrm{~atm}$.

Regarding char yield, PVC was found to provide a relatively large positive synergy with a maximum value of $8 \mathrm{wt} \%$ at $30 \mathrm{wt} \% \mathrm{PVC}$ content, whereas PS only showed a slightly positive synergy $(2.5 \mathrm{wt} \%$ maximum). The addition of PS generally increased oil yield and lowered gas yield relative to the pyrolysis of pure PW. However, for oil production, a small negative synergy was seen for PS, although the reverse effect on gas yield was observed. Interestingly, the presence of PVC had a significant positive synergy on oil yield with a maximum value of $11 \mathrm{wt} \%$ at $50 \mathrm{wt} \%$ PVC content. This was linked to a strong negative synergy in gas (mainly $\mathrm{HCl}$ ) production, where a maximum synergy of $18 \mathrm{wt} \%$ was observed at $30 \mathrm{wt} \%$ PVC content.

With respect to the influence of plastic type and ratio on gas specie yield, the addition of PS resulted in positive synergies in the formation of $\mathrm{H}_{2}, \mathrm{CH}_{4}, \mathrm{CO}$ and $\mathrm{CO}_{2}$, although insignificant interactions were seen for $\mathrm{C}_{x} \mathrm{H}_{y}$ compounds. With regard to PVC, an increase in $\mathrm{H}_{2}$ yield was observed accompanied by a positive synergistic effect. Furthermore, $\mathrm{HCl}$ gas yield was found to decrease by $53.6 \mathrm{wt} \%$ when PVC content was decreased from 100 to $30 \mathrm{wt} \%$. A further analysis of the distribution of $\mathrm{Cl}$ molecules in the char, gas and oil products using thermodynamic equilibrium calculations, revealed that $\mathrm{Cl}$ was largely fixed in the condensed oil phase mainly as dissolved $\mathrm{HCl}$ gas in the water fraction, although some chlorine was also trapped in the solid residue in the form of metal chloride salts. Concerning the gas lower heating value (LHV), the addition of PS and PVC to the sample had an insignificant synergistic effect below $50 \mathrm{wt} \%$ plastic content.

Our work consolidates the understanding of the effect of synergy between wood, PVC and PS, on product yield, gas specie yield and gas heating value under operating conditions that favor gas production. Moreover, by comparing the results of our work with literature, we have identified the need for a better understanding of the interactions involving $\mathrm{HCl}$ during co-pyrolysis of biomass and PVC. Our future work will therefore focus on modelling the kinetics of interactions between poplar wood and PVC during co-pyrolysis.

\section{References}

[1] JRC-IPTS. Study on the selection of waste streams for end-of-waste assessment. JRC Scientific and Technical Reports, EUR 24362.ftp://jrc.es/pub/EURdoc/EURdoc/ 
JRC58206.pdf.

[2] Pinto F, Miranda M, Costa P. Production of liquid hydrocarbons from rice crop wastes mixtures by co-pyrolysis and co-hydropyrolysis. Fuel 2016;174:153-63 http://dx.doi.org/10.1016/j.fuel.2016.01.075. URL:http://linkinghub.elsevier. $\mathrm{com} / \mathrm{retrieve/pii/S001623611600096X.}$

[3] Abnisa F, Wan Daud WMA. A review on co-pyrolysis of biomass: an optional technique to obtain a high-grade pyrolysis oil. Energy Convers Manage 2014;87:71-85. http://dx.doi.org/10.1016/j.enconman.2014.07.007. URL:http:// www.sciencedirect.com/science/article/pii/S019689041400630X.

[4] Cornelissen T, Jans M, Yperman J, Reggers G, Schreurs S, Carleer R. Flash co-pyrolysis of biomass with polyhydroxybutyrate: Part 1. Influence on bio-oil yield, wate content, heating value and the production of chemicals. Fuel 2008;87(12):2523-32. http://dx.doi.org/10.1016/j.fuel.2008.02.024. URL:http://linkinghub.elsevier. com/retrieve/pii/S0016236108000847

[5] Cornelissen T, Yperman J, Reggers G, Schreurs S, Carleer R. Flash co-pyrolysis of biomass with polylactic acid. Part 1: Influence on bio-oil yield and heating value. Fuel 2008;87(7):1031-41, http://dx doi.org/10.1016/j.fuel.2007.07.019. URL:http://linkinghub.elsevier.com/retrieve/pii/S0016236107003419.

[6] Liu W-J, Tian K, Jiang H, Zhang X-S, Yang G-X. Preparation of liquid chemical feedstocks by co-pyrolysis of electronic waste and biomass without formation of polybrominated dibenzo-p-dioxins. Bioresour Technol 2013;128:1-7. http://dx.doi org/10.1016/j.biortech.2012.10.160. URL:http://linkinghub.elsevier.com/ retrieve/pii/S0960852412016690.

[7] Johannes I, Tiikma L, Luik H. Synergy in co-pyrolysis of oil shale and pine sawdust in autoclaves. J Anal Appl Pyrol 2013;104:341-52. http://dx.doi.org/10.1016/j. jaap.2013.06.015. URL:http://linkinghub.elsevier.com/retrieve/pii/ S0165237013001459.

[8] Grieco EM, Baldi G. Pyrolysis of polyethylene mixed with paper and wood: interaction effects on tar, char and gas yields. Waste Manage 2012;32(5):833-9. http:// dx.doi.org/10.1016/j.wasman.2011.12.014. URL:http://www.sciencedirect.com/ science/article/pii/S0956053X11005848.

[9] Yang J, Rizkiana J, Widayatno WB, Karnjanakom S, Kaewpanha M, Hao X, Abudula A, Guan G. Fast co-pyrolysis of low density polyethylene and biomass residue for oil production. Energy Convers Manage 2016;120:422-9. http://dx.doi.org/10.1016/j. enconman.2016.05.008. URL:http://linkinghub.elsevier.com/retrieve/pii/ S0196890416303740.

[10] Papuga S, Gvero P, Vukic L. Temperature and time influence on the waste plastics pyrolysis in the fixed bed reactor. Therm Sci 2016;20(2):731-41. http://dx.doi.org/ 10.2298/TSCI141113154P. URL:http://www.doiserbia.nb.rs/Article.aspx?ID = 0354-98361500154P.

[11] Sun J-P, Sui S-J, Zhang Z-J, Tan S, Wang Q-W. Study on the pyrolytic behavior of wood-plastic composites using Py-GC/MS. BioResources 2013;8:6196-210.

[12] Paradela F, Pinto F, Gulyurtlu I, Cabrita I, Lapa N. Study of the co-pyrolysis of biomass and plastic wastes. Clean Technol Environ Pol 2009;11(1):115-22. http:// dx.doi.org/10.1007/s10098-008-0176-1.

[13] Sharypov VI, Marin N, Beregovtsova NG, Baryshnikov SV, Kuznetsov BN, Cebolla VL, Weber JV. Co-pyrolysis of wood biomass and synthetic polymer mixtures. Part I: influence of experimental conditions on the evolution of solids, liquids and gases. $J$ Anal Appl Pyrol 2002;64(1):15-28. http://dx.doi.org/10.1016/S0165-2370(01) 00167-X. URL:http://www.sciencedirect.com/science/article/pii/ S016523700100167X

[14] Oyedun AO, Tee CZ, Hanson S, Hui CW. Thermogravimetric analysis of the pyrolysis characteristics and kinetics of plastics and biomass blends. Fuel Proces Technol 2014;128:471-81. http://dx.doi.org/10.1016/j.fuproc.2014.08.010. URL:http://www.sciencedirect.com/science/article/pii/S0378382014003464

[15] Anal E, Uzun BB, Ptn AE. Bio-oil production via co-pyrolysis of almond shell as biomass and high density polyethylene. Energy Convers Manage 2014;78:704-10. http://dx.doi.org/10.1016/j.enconman.2013.11.022. URL:http://linkinghub. elsevier.com/retrieve/pii/S0196890413007437.
[16] Caglar A, Aydinli B. Isothermal co-pyrolysis of hazelnut shell and ultra-high molecular weight polyethylene: the effect of temperature and composition on the amount of pyrolysis products. J Anal Appl Pyrol 2009;86(2):304-9. http://dx.doi. org/10.1016/j.jaap.2009.08.002. URL:http://linkinghub.elsevier.com/retrieve/ $\mathrm{pii} / \mathrm{S} 0165237009001156$.

[17] Williams EA, Williams P. The pyrolysis of individual plastics and a plastic mixture in a fixed bed reactor. Chem Technol Biotechnol.

[18] Aepelio Aullar A, Ptn AE. Products characterization study of a slow pyrolysis of biomass-plastic mixtures in a fixed-bed reactor. J Anal Appl Pyrol 2014;110:363-74. http://dx.doi.org/10.1016/j.jaap.2014.10.002. URL:http:// www.sciencedirect.com/science/article/pii/S0165237014002526.

[19] Matsuzawa Y, Ayabe M, Nishino J. Acceleration of cellulose co-pyrolysis with polymer. Polym Degrad Stab 2001;71(3):435-44. URL:http://www.sciencedirect. com/science/article/pii/S0141391000001956.

[20] Matsuzawa Y, Ayabe M, Nishino J, Kubota N, Motegi M. Evaluation of char fuel ratio in municipal pyrolysis waste. Fuel 2004;83(11-12):1675-87. http://dx.doi. org/10.1016/j.fuel.2004.02.006. URL:http://linkinghub.elsevier.com/retrieve/pii/ S0016236104000468.

[21] Abnisa F, Daud WW, Sahu J. Pyrolysis of mixtures of palm shell and polystyrene: an optional method to produce a high-grade of pyrolysis oil. Environ Prog Sustain Energy 2014;33(3):1026-33. http://dx.doi.org/10.1002/ep.11850.

[22] Abnisa F, Wan Daud W, Ramalingam S, Azemi MNBM, Sahu J. Co-pyrolysis of palm shell and polystyrene waste mixtures to synthesis liquid fuel. Fuel 2013;108:311-8. http://dx.doi.org/10.1016/j.fuel.2013.02.013. URL:http://linkinghub.elsevier. com/retrieve/pii/S0016236113001014.

[23] Brebu M, Ucar S, Vasile C, Yanik J. Co-pyrolysis of pine cone with synthetic polymers. Fuel 2010;89(8):1911-8. http://dx.doi.org/10.1016/j.fuel.2010.01.029. URL:http://linkinghub.elsevier.com/retrieve/pii/S0016236110000372.

[24] Zhou H, Wu C, Onwudili JA, Meng A, Zhang Y, Williams PT. Effect of interactions of PVC and biomass components on the formation of polycyclic aromatic hydrocarbons (PAH) during fast co-pyrolysis. RSC Adv 2015;5(15):11371-7. http://dx. doi.org/10.1039/C4RA10639C.

[25] Marongiu A, Faravelli T, Bozzano G, Dente M, Ranzi E. Thermal degradation of poly (vinyl chloride). J Anal Appl Pyrol 2003;70(2):519-53. http://dx.doi.org/10.1016/ S0165-2370(03)00024-X. URL:http://linkinghub.elsevier.com/retrieve/pii/ S016523700300024X.

[26] Aepelioullar A, Ptn AE. A pyrolysis study for the thermal and kinetic characteristics of an agricultural waste with two different plastic wastes. Waste Manage Res 2014;32:971-9. URL:http://wmr.sagepub.com/content/32/10/971.

[27] Zhou H, Long Y, Meng A, Li Q, Zhang Y. Interactions of three municipal solid waste components during co-pyrolysis. J Anal Appl Pyrol 2015;111:265-71. http://dx. doi.org/10.1016/j.jaap.2014.08.017. URL:http://linkinghub.elsevier.com/ retrieve/pii/S0165237014001958.

[28] Kuramochi H, Nakajima D, Goto S, Sugita K, Wu W, Kawamoto K. HCl emission during co-pyrolysis of demolition wood with a small amount of PVC film and the effect of wood constituents on $\mathrm{HCl}$ emission reduction. Fuel 2008;87(13-14):3155-7. http://dx.doi.org/10.1016/j.fuel.2008.03.021. URL:http://linkinghub.elsevier.com/retrieve/pii/S0016236108001245.

[29] Yu J, Sun L, Ma C, Qiao Y, Yao H. Thermal degradation of PVC: a review. Waste Manage.http://dx.doi.org/10.1016/j.wasman.2015.11.041. URL:http://www. sciencedirect.com/science/article/pii/S0956053X15302233.

[30] Zhou H, Long Y, Meng A, Li Q, Zhang Y. Thermogravimetric characteristics of typical municipal solid waste fractions during co-pyrolysis. Waste Manage 2015;38:194-200. http://dx.doi.org/10.1016/j.wasman.2014.09.027. URL:http:// www.sciencedirect.com/science/article/pii/S0956053X14004498.

[31] Said M, Cassayre L, Dirion J-L, Nzihou A, Joulia X. Behavior of heavy metals during gasification of phytoextraction plants: thermochemical modelling. Computer aided chemical engineering. vol. 37. 2015. p. 341-6. 